\title{
Constitutionality and Constitution of the National Company Law Tribunal and the National Company Law Appellate Tribunal
}

\author{
Karan Kamath*
}

\begin{abstract}
Modern states, with their overwhelmingly encompassing jurisdictions, cannot rely on the traditional judiciary for expeditiousness. Hence, administrative adjudication is on the rise. The National Company Law Tribunal and the National Company Law Appellate Tribunal were introduced into company law, fifteen years ago, in 2002. The new company law legislation of 2013 acclimatized some of the suggestions made by the Supreme Court and the Madras High Court, but not all. Despite being established and functioning for a year now, the tribunals suffer from certain infirmities which should have been rectified after the judiciary had advised so. This article traces the journey of the constitution of the tribunals, examines the constitutionality of the provisions as they stand, and concludes by suggesting certain modifications to the existing legislation.
\end{abstract}

Keywords: Companies (Amendment) Bill, 2016, Constitutionality, Judicial Members, Technical Members, Tribunal

\section{Introduction}

Administrative adjudication is an essential part of modern states. As Wade and Phillips put it, questions in a modern state "cannot be

\footnotetext{
* Symbiosis Law School, Pune, India; karankamath15@gmail.com
} 
appropriately solved by applying objective legal principles", but rather, "in public interest, as matter of social policy". ${ }^{1}$ Technical expertise is considered a better alternative to the judicial principles of a judge. Hence, the desirability of tribunals is at its maxima in various faculties. ${ }^{2}$ Specialized adjudication is sought in many fields of law, including patents, antitrust, commerce etc. Although alternative dispute resolution is seen as an enterprise incorporating such specialization, it nevertheless suffers from faults such as its inability to create precedents. ${ }^{3}$ Therefore, in areas such as company litigation, there is a need for a specialized administrative court. Such bodies assist in overcoming multiple shortcomings of the traditional court systems, apart from the advantage of having technical members present on the panel. For example, the envisioned company tribunal reduces the longevity of a winding up proceeding that could span across twenty to twenty-five years, to merely two years. ${ }^{4}$ The consideration that such non-traditional courts degrade the ordinary court system is mythical. In fact, specialized commercial courts have ushered in an unprecedented era of business facilitation in jurisdictions where they are constituted..$^{5}$ Therefore, tribunals for company disputes become a necessity not only for their expeditiousness and special expertise, but also for proliferation of trade and commerce.

In India, miscellany bodies act as an expeditious and advantageous alternative to courts of law, with recent additions to this list being the National Company Law Tribunal (hereinafter, the Tribunal), and

${ }^{1}$ WADE AND PHILLIPS, CONSTITUTIONAL LAW 699 (1965).

21 G P SINGH AND ALOK ARADHE (EDS), M P JAIN AND S N JAIN PRINCIPLES OF ADMINISTRATIVE LAW 696-699 (2010).

3 Carl N Pickereill, Specialised Adjudication in an Administrative Forum: Bridging the Gap between Public and Private Law, 82(4) Notre Dame L. Rev. 1605, 1605-6 (2013).

${ }^{4}$ Union of India v R. Gandhi, (2010) 11 S.C.C. 1, $₫ 4$.

5 Justice Jack B Jacobs, The Role of Specialised Courts in Resolving Corporate Governance Disputes in the United States and in the EU: An Amercan Judge's Perspective, THE ORGANISATION FOR ECONOMIC CO-OPERATION AND DEVELOPMENT (Mar. 18, 2006), www.oecd.org/ daf/ ca/ corporategovernanceprinciples/37188750.pdf. 
the National Company Law Appellate Tribunal (hereinafter, the Appellate Tribunal). The two have been constituted recently, ${ }^{6}$ but have been part of the law, on paper for nearly one and a half decade. They were incorporated in law, subsequently pulled into courts for doubts over their constitutionality, reintroduced with some changes in a new legislation and further petitioning continued, etc. ${ }^{7}$ Regardless of the fact that the tribunals have undergone an elaborate process of legal scrutiny, they are still frowned upon for multiple reasons as they require sundry amendments to be compatible with the Constitution. This article considers various provisions of the Companies Act, 2013, relating to the tribunals and critically analyses them with respect to their constitutionality, and suggests certain changes in the prevailing position, to ameliorate unconstitutionality or other shortcomings.

\section{The Constitution of the Tribunals}

The adjudication relating to company matters in India was divided into three separate jurisdictions before the Tribunal was envisioned. Firstly, there was the Company Law Board, then the Board for Industrial and Financial Reconstruction, and the High Courts, having their own subject matter to adjudicate upon. ${ }^{8}$ The multiplicity of jurisdictions was indeed vexatious. Nevertheless, the suggestion for the Tribunal came from an unlikely source. A committee was established under the chairmanship of Justice Vettath Balakrishna Eradi, to analyze the processes relating to winding up of companies. Despite not having any pre-sanctioned matter of reference, the Committee advised that there was a need

6 SO 1932(E), Ministry of Corporate Affairs - Notification, (Nov.1,2016), nclt.gov.in/orders/Notification_02062016_II.pdf.

7 Mamata Biswal, Company Litigation and Jurisdictional Issues: An Incessant Challenge in India: Prevailing Multiple Jurisdiction to a Complex Jurisdiction under the Companies Act, 2013, 2 Supreme Court Cases Journal 19, 20 (2017) (Hereinafter, Biswal).

${ }^{8}$ Report of the High-Level Committee on Law Relating to Insolvency and Winding-up of Companies (2000), Preface, I 4, (Hereinafter, Eradi Committee Report). 
for a Company Law Tribunal. ${ }^{9}$ Moreover, the Committee expressly laid down that appeals from the proposed Tribunal should lie in the High Court. It categorically refused the need for an Appellate Tribunal. ${ }^{10}$ The Parliament however, for unknown reasons and contrary to the suggestions of the Reserve Bank of India ${ }^{11}$ and the International Monetary Fund, ${ }^{12}$ chose to establish the Appellate Tribunal, through the Companies (Second Amendment) Act, 2002.13

The 2002 Amendment to the Companies Act, 1956 was challenged in the Madras High Court, and subsequently an appeal was desired to the Supreme Court by both the original petitioner and the government. Both the Courts while upholding the constitutional validity of the tribunals, suggested certain guidelines to reform certain provisions, which were, in the opinion of the courts, unconstitutional or legally unpleasant. Meanwhile, the Parliament enacted the Companies Act, 2013 replicating certain provisions, which the Supreme Court had asked it to reform, as they suffered from unconstitutionality. ${ }^{14}$ The Court, while asking for the changes to be incorporated, reiterated its previous dictum. ${ }^{15}$ Regardless of this, the government chose to constitute the tribunals in 2016. The legislation, as it stands, is still unreformed to a large extent, and multiple provisions require amendment.

\section{The Constitutionality of the Tribunals}

The suggestions of the Supreme Court and the Madras High Court can be roughly divided into two categories - those relating to membership, appointments, and like; and those concerned with procedures and ancillary affairs

93 A Ramaiya, A Guide to THE COMPANiES ACt 5575 (18 (Hereinafter, RAMAIYA).

10 Eradi Committee Report, 94.5

11 Report of the Advisory Group on Bankruptcy Laws (2001).

12 RAMAIYA, supra note 9 , at 5576.

13 Companies (Second Amendment) Act, No. 11, Acts of Parliament, 2003.

14 Biswal,supra note 7, at 20.

${ }^{15}$ Madras Bar Association v. Union of India, (2015) 8 S.C.C. 583. 


\section{III.1 Membership and Ancillary Provisions}

The Companies Act contains numerous complex and detailed provisions that lay down varied aspects of membership of the tribunal - qualifications of judicial members, technical members, chairperson, and president, their selection process and removal etc. Most of these provisions have been identified by the Courts as unconstitutional. ${ }^{16}$

\section{i. Judicial Members}

Judicial Members of the Tribunal are to be either serving or former High Court judges, serving or former District Court judges, with an experience in the judiciary of five years, or lastly advocates with ten years of practice. ${ }^{17}$ The Companies (Second Amendment) Act, 2002 had also validated the appointment of certain Indian Legal Service officials and Indian Company Law Service officials as Judicial Members. ${ }^{18}$ The Courts did not look at this provision favorably, by noting that such officers can be appointed as Technical Members, but not judicial Members. ${ }^{19}$ The 2013 Act does not have this provision, and therefore this provision should prima facie be acceptable to the Courts.

The Appellate Tribunal has serving or retired High Court judges as its Judicial Members. Further, Judicial Members of the Tribunal who have served in that position for five years, can also be appointed in a similar manner. ${ }^{20}$ Earlier, there was no distinction between Technical and Judicial Members of the Appellate Tribunal unlike now. ${ }^{21}$ Hence, the new statute has reasonably reformed the position of Judicial Members of the Appellate Tribunal.

\footnotetext{
${ }^{16}$ Madras Bar Association v. Union of India, (2015) 8 S.C.C. 583; Union of India v. R. Gandhi, (2010) 11 S.C.C. 1, para 120.

$17 \S 409$, the Companies Act, No.18, Acts of Parliament, 2013.

$18 \S 10 F D$, the Companies Act, No.1, Acts of Parliament, 1956.

19 Union of India v. R. Gandhi, (2010) 11 S.C.C. 1, para 120(i).

$20 \S 411$, the Companies Act, No.18, Acts of Parliament, 2013.

${ }^{21} \S 10 F R$, the Companies Act, No.1, Acts of Parliament, 1956.
} 


\section{ii. Technical Members}

The requirements for Technical Members have been subject to more criticism, compared to those of Judicial Members. The Courts, while examining provisions relating to Technical Members of the Tribunal, suggested that since Technical Members must be of the same status as Judicial Members, i.e. High Court judges, they should have an equivalent experience in their respective field. ${ }^{22}$ The clause allowing Joint Secretaries as Technical Members was contrary to this consideration, for it has been analyzed that these officers do not have the requisite experience to be held at par with Judicial Members of the same tribunal. Only Secretaries and Additional Secretaries were held to be at par with High Court judges. ${ }^{23}$ This was with regard to the old provisions, which were egregiously continued in the new legislation. ${ }^{24} \mathrm{~A}$ later writ petition filed by the Madras Bar Association compelled the Court to reiterate its verdict once more. ${ }^{25}$ The government was receptive this time, and the pending Companies (Amendment) Bill, 2016 does incorporate this change, and allows only appointment of Additional Secretaries and Secretaries for the post. ${ }^{26}$ This Amendment, along with this particular clause was passed by the House of the People without changes in late July, 2017.27 While the Amendment may be passed in the Upper House as well, that may not solve the issue per se. Clause (e), of sub-section (3), of Section 409 allows appointment of 'persons with proven ability' in certain fields as Technical Members. Joint Secretaries may still be appointed under this provision. Adequate safeguards must be in place to ensure that there is no bypassing of the Supreme Court's guidelines. The Appellate Tribunal on the other hand allows appointment of only 'persons with proven ability'. The eligibility criteria aside, the entire object of appointing such Technical Members on the Appellate Tribunal is contestable. The sole

\footnotetext{
${ }^{22}$ Union of India v. R. Gandhi, (2010) 11 S.C.C. 1, para 120(ii).

${ }^{23} I d$.

24 RAMAIYA, supra note 9, at 5592.

${ }_{25}$ Madras Bar Association v. Union of India, (2015) 8 S.C.C. 583, ๆ 22-28.

26 Clause 78, the Companies (Amendment) Bill, 2016 (No 73 of 2016).

${ }^{27}$ Clause 82, the Companies (Amendment) Bill, 2016 (No 73-C of 2016).
} 
objective of the Appellate Tribunal is to hear appeals from the lower Tribunal, solving substantive questions of law, which is a judicial function. Further, the only reason to appoint an Appellate Tribunal is to ensure expeditious disposal of cases. What contribution can a man of technical expertise provide while considering pure questions of law? In the light of these contentions, it can be argued that Technical Members are not necessarily required on the Appellate Tribunal. Unfortunately, the courts did not consider this question, and thus, it remained unsolved. ${ }^{28}$ But, it cannot be denied that there is a considerable ground for reconsideration of the position of Technical Members on the Appellate Tribunal.

\section{iii. Chairperson and President}

The Companies Act provides for a President to chair the Tribunal and a Chairperson to preside over the Appellate Tribunal. The former office is open only to a serving or retired High Court judge with a five-year experience, while the Chairpersonship of the Appellate Tribunal is open to a sitting or retired Supreme Court Justice, or a Chief Justice of a High Court. ${ }^{29}$ Earlier, the Chairpersonship was specifically reserved only for retired Supreme Court judges, 30 but now, the ambit has been widened. Similarly, the President could be a person who was "qualified to be" a High Court judge, 31 a provision which providentially does not find any place in the new legislation, ensuring that the office remains in the hands of a member of the higher judiciary.

Section 415 of the Act lays down that, in an event where the Chairperson or the President is unavailable or incapable of discharging their duties, then, the 'senior-most' member can temporarily serve in that position. The seemingly harmless provision has a fundamental flaw, which has not been considered by the Courts. The positions of Chairperson and President are to be

${ }^{28}$ RAMAIYA, supra note 9 , at 5594-5595.

$29 \S 409$ and $\S 411$, the Companies Act, No.18, Acts of Parliament, 2013.

$30 \S 10 F R$, the Companies Act, No.1, Acts of Parliament, 1956.

${ }^{31} \mathrm{Id}$. at§10FD. 
held by members of the judiciary, while the 'senior-most' member of the Tribunal or the Appellate Tribunal may not certainly be a Judicial Member. Therefore, the possibility that a Technical Member may be required to conduct duties of those two offices, specifically reserved for judges of the higher judiciary, is a disagreeable occurrence.

\section{iv. Selection Committee}

The members and presiding officers of the tribunals are to be appointed by a Selection Committee, which consists of two judges and three bureaucrats. Chief Justice of India is the ex officio Chairperson of this Committee. ${ }^{32}$ The majority given to the executive members is a direct assault on the independence of the judiciary. This Committee is supposed to be a reformed version of the previous one, but instead, it suffers from the same fault. The earlier enactment had mandated a Committee of five members, the Chief Justice and four civil servants. ${ }^{33}$ The Supreme Court, understandably did not accept this proposition. Instead, it suggested that there be an equal number of judges and mandarins

- two each, and the Chief Justice be accorded the pivotal casting vote to resolve stalemates. ${ }^{34}$ Turning a blind eye to this advice, the legislature enacted an alternative, which still does not incorporate the required change, or achieve the intended goal. This has been pointed out by the Supreme Court during the subsequent petition as well. ${ }^{35}$ Having said that, there is the aforementioned amendment passed by the House of the People, which is inclusive of this change. ${ }^{36}$ It is imperative that this modification passes in the Council of States, as any appointment committee that has neither a majority of judicial members, nor allows primacy to judiciary, is a constant, persisting threat to the independence of the judiciary.

$32 \S 412$, the Companies Act, No.18, Acts of Parliament, 2013.

${ }^{33} \S 10 F X$, the Companies Act, No.1, Acts of Parliament, 1956.

34 Union of India v. R. Gandhi, (2010) 11 S.C.C. 1, 1 120(x).

${ }^{35}$ Madras Bar Association v. Union of India, (2015) 8 S.C.C. 583, ๆ 29-33.

36 Clause 80, the Companies (Amendment) Bill, 2016 (No. 73 of 2016). 


\section{v. Term of Office}

All members of the tribunals are eligible for a renewable term of five-years. The retirement age for the Chairperson, Members of the Appellate Tribunal, the President, and Members of the Tribunal is seventy, sixty-seven, sixty-seven, and sixty-five years respectively, while the uniform minimum age for appointment is fifty. ${ }^{37}$ The earlier law allowed for three-year renewable terms with no minimum eligibility age. ${ }^{38}$ The idea that judges will be dependent on an external authority for their reappointment raises the apprehension of a threat to the independence of the judiciary. This dependence may press them into passing orders favorable to the government, as was identified by the Supreme Court. ${ }^{39}$

The United States Supreme Court encountered a similar problem. In Northern Pipeline Company Limited $v$ Marathon Pipe Line Co, ${ }^{40}$ the Court was called upon to examine the constitutionality of certain Bankruptcy Courts, established by the United States Congress. The legislation passed by the Congress allowed non-renewable terms of fourteen years, but judges could be removed before completion of their terms by the executive, in certain situations, without any procedure of impeachment. This contradicted the American Constitutional principle of life tenure for judges, which the Court believed would threaten the neutrality of judges. In a similar manner, it can be understood easily by anybody, that the dependency on the executive, for reappointment, may compel the judges to reconsider their even-handedness.

National Tax Tribunal, another quasi-judicial body similar to the Appellate Tribunal, created by the Parliament to deal with tax litigation, was struck down by the Supreme Court, citing the renewability of the judges' terms as contrary to an independent judiciary. ${ }^{41}$ Therefore, analogously concluding, Section 413 of the

$37 \S 413$, the Companies Act, No.18, Acts of Parliament, 2013.

38 §10FE and § 10FT, the Companies Act, No.1, Acts of Parliament, 1956.

${ }^{39}$ RAMAIYA, supra note 9 , at 5598.

40 Northern Pipeline Company Limited v Marathon Pipe Line Co, 458 US 50 (1982).

${ }^{41}$ Madras Bar Association v. Union of India, (2014) 10 S.C.C. 1. 
Act should be revisited, and modified to protect judicial independence.

\section{vi. Removal of Members}

Section 417 deals with removal of members. The government, in consultation with the Chief Justice of India, can debar members on the grounds of insolvency, conviction for offence involving moral turpitude, mental or physical incapability etc. Apart from insolvency, which is determined by a court of law, other grounds must be proved in an inquiry conducted by a Supreme Court Justice. The Supreme Court has laid down that with respect to appointment and removal of judges, the term 'consultation' is to be taken as 'concurrence'. ${ }^{42}$ This is to enhance the independence of judiciary to a magnitude where the paramount head of judiciary enjoys unprecedented primacy of opinion in matters such as appointment and removal of judiciary, which lie at the heart of judicial independence. In the aforementioned section, the terms are used interchangeably, which may be a non-issue, yet should be resolved by inclusion of the word 'concurrence' throughout the provision. 43

\section{III.2 Procedure and Particulars}

\section{i. Benches of the Tribunal}

The Principal Bench of the Tribunal is at Delhi, presided over by the President. Generally, the Tribunal is supposed to deal with cases consisting of benches comprising of two members, one Technical and one Judicial. Further, a single Judicial Member bench can also be established if the need so arises. Special benches, consisting of three and more members can also be constituted, provided that Judicial Members are always in a majority. All questions are to be resolved by majority, while in a situation where the two members of an ordinary bench disagree with each other,

42 Supreme Court Advocates-on-Record Association v. Union of India, (1993) 4 S.C.C. 441.

${ }^{43}$ RAMAIYA, supra note 9 , at 5606. 
the President can refer such an issue to a third person, for his determinative decision. ${ }^{44}$

\section{ii. Orders and Appeals}

The Tribunal is empowered to pass any orders as it deems fit. The only prerequisite is that it should hear both parties, before passing such orders. Additionally, it can rectify any mistake in its orders, within two years of passage of such orders, if one of the parties brings it to their notice. Any person aggrieved by an order, has the liberty to appeal to the Appellate Tribunal, within forty-five days of receiving the order. ${ }^{45}$ Usage of the term 'any person aggrieved' is important here, as not all persons who feel disappointed by a judgment are aggrieved. Persons who are wrongfully deprived of something can be termed as such, and only they have a right to appeal such a decision. ${ }^{46}$ The powers of the Tribunal are wide and far-reaching, and thus, it can have overwhelming impact on multiple persons. Therefore, it was prudent on the part of the legislature to use the term 'any person aggrieved', and not 'parties aggrieved'. The Delhi High Court, while referring to the Company Law Board, has recorded similar observations. ${ }^{47}$

Both tribunals are under a statutory mandate to complete proceedings within three months. One of the principal purposes of the legislation, i.e. expeditious disposal of cases by the administrative adjudicating bodies, is codified in Section 422 . There is an exception for certain circumstances, where a proceeding cannot be completed within the stipulated period of time, and the President or the Chairperson deems it fit that an extension of deadline, not exceeding ninety days, be granted. By conservative estimates, a proceeding filed before the Tribunal should be ideally disposed of within, a maximum of thirteen to fourteen months, by both tribunals.

\footnotetext{
$44 \S 419$, the Companies Act, No.18, Acts of Parliament, 2013.

$45 \mathrm{Id}$. at $\$ 420$.

46 Adi Pherozeshah Gandhi v. H. M. Seervai, A.I.R. 1971 S.C. 385.

47 Industrial Development Bank of India v. C.L.B., (2007) 81 C.L.A. 356 (Del).
} 
Appellate Tribunals orders can be appealed directly to the Supreme Court, before expiry of a limitation period of sixty days. Articles 226 and 227 of the Constitution provide that a High Court has jurisdiction over all courts and tribunals in its territorial jurisdiction. Hence, every Appellate Tribunal will be technically under the purview of a High Court. As those Articles are the basic structure of the Constitution, they cannot be parted from. ${ }^{48}$ Therefore, every Appellate Tribunal order could be challenged in the High Court. However, as the legislature has provided for a direct route to the Supreme Court, unnecessary challenges in the High Court may not be prudent. Additionally, High Courts are expected not to mingle in such matters, unless there is a gross violation of principles of natural justice. ${ }^{49}$

\section{iii. Contempt}

Tribunals have a power to punish for their own contempt. ${ }^{50}$ It was argued in at least one writ petition, that such a power would be unconstitutional. This attempt was unsuccessful. The petitioner had argued that such a power would be "unhealthy". ${ }^{51}$ There is nothing substantial to claim that this power is invalid or unconstitutional.

\section{Conclusion}

On careful scrutiny and inspection of the tribunals' provisions and their constitutionality as laid down by the Courts, it can be concluded that the unincorporated suggestions are still a vexatious blot on the constitutionality of the tribunals. The author proposes certain recommendations:

48 S. P. Sampath Kumar v. Union of India, (1987) 1 S.C.C. 124; L. Chandra Kumar v. Union of India, (1997) 3 S.C.C. 261.

49 RAMAIYA, supra note 9, at 5613; Surya Dev Rai v. Ram Chander Rai, (2003) 6 S.C.C. 675, q 39.

$50 \S 425$, the Companies Act, No.18, Acts of Parliament, 2013.

51 Madras Bar Association v. Union of India, (2015) 8 S.C.C. 583, ๆ 34. 


\section{i. Qualifications of Technical Members of the Tribunal}

Qualifications of Technical Members as of now are not harmonious with the Supreme Court's guidelines. To achieve that end, there would be two modifications required to be made to the Companies Act. First, the provision enabling Joint Secretaries to be Technical Members should be amended to add only Additional Secretaries and Secretaries. This would ensure that only persons who have a similar grade as High Court judges are on the Tribunal. And second, to disallow colorable use of the legislation, the provision allowing 'persons with proven ability' be amended in a manner that would not allow Joint Secretaries to bypass preceding Sections, or an express proviso be attached disabling Joint Secretaries from availing protection of that sub-section. The Companies (Amendment) Bill, 2016 does incorporate the first change. If passed by the Council of States, that would solve the prevailing issues, and bring the Tribunal in line with the Apex Court's interpretation. However, the provision of 'proven ability' still allows a route for bypass.

\section{ii. Necessity of Technical Members on the Appellate Tribunal}

The question of whether Technical Members enrich proceedings that determine an issue of law, is intriguing one. The legislature's prudence of adding them cannot be outright rejected. There must be a thorough and reasoned debate on this issue. Even if one assumes that Technical Members are not on the Appellate Tribunal, this would defeat the entire purpose of having such an appellate body. If a group of High Court judges are going to decide these appeals, one may as well abolish the Appellate Tribunal, and let High Courts determine matters directly, in consonance with the suggestions that the Eradi Committee had initially proposed. Alternatively, if one chooses to keep Technical Members on board, their presence is worthless. Technical expertise can be a commendable characteristic for the Tribunal, but that cannot be the case with Appellate Tribunal. Further research and discussion is required with regards to this aspect.

\section{iii. Acting Presidents and Chairpersons}

Section 415 as mentioned earlier, allows Technical Members to serve on offices reserved for persons with judicial background. 
Although temporary or interim positions, such temporary positions would manifestly be wrong, for they allow a disparity in the principle that a Judicial Member must be at the helm of the tribunals, in the interests of independence of judiciary. Thus, the word 'Judicial' should be added between "senior-most" and 'Member' to resolve the issue.

\section{iv. Age Qualifications}

There is a requirement that all members of both tribunals should have completed fifty years of age, a condition which was absent in the older law. Even the Supreme Court can have judges, who are fifteen years younger -52 there is nothing which substantiates this absurd condition. Therefore, this specification primarily keeps capable adjudicators from being appointed. The requirement of age should be thus, reconsidered.

\section{v. Renewability of Terms and Independence of Judiciary}

The renewable terms granted to members of the Tribunal and of the Appellate Tribunal are unpleasant and odious. Reappointment is dependent on one authority or another, which is not under an obligation to provide reasons for rejecting reappointment. Thus, it can cause blotting of neutrality of individual judges and the Tribunal itself. Therefore, it is reasonable that non-renewable but longer terms are accorded on the judges, or the reappointment process is freed for administrative control.

\section{vi. Consultation and Concurrence}

Regardless of the Supreme Court's judgment that 'consultation' with regards to appointment and removal of judges mandatorily being read as 'concurrence', the independent existence of the two terms in the provision relating to removal of members is nauseating. Ideally, there should be an amendment changing every 'consultation' with 'concurrence'.

52 INDIA CONST. art. 124. 


\section{vii. Third Person Referrals}

If there is a difference of opinion between two members of a bench, the President has the authority to refer such a question to a third member. This member, who will have the power to determine the dispute, can be a Judicial or a Technical Member. If he is the latter, then technically that issue has been solved by two Technical Members, which is contrary to the overtly obvious intention of the legislature, which chiefly purports to have questions determined by a majority of Judicial Members. Therefore, term 'Judicial' should be included before 'Member' in Section 419.

The Tribunal and the Appellate Tribunal are a commendable system of administrative adjudication which can streamline company law issues, which is healthy for trade and commerce in the country. But adaption of commerce friendly policy should not prompt withdrawal of our much cherished legal and juristic principles. Therefore, the specific amendments mentioned above should be implemented, or considered, to make this admirable piece of legislation in consonance with the Constitution. 